\title{
A CLINICAL CASE OF REMOVING A RESIDUAL FOR- EIGN BODY FROM THE LEFT SUPRACLAVICULAR REGION
}

1 - Kharkiv National Medical University

2 - State Enterprise “V.T. Zaitsev Institute of General and Emergency Surgery of the National Academy of Medical Sciences of Ukraine"

\begin{abstract}
Residual foreign bodies in soft tissues are one of the main causes of chronical infection lesions and decrease in life quality. Surgical treatment is the most common way to relieve the patient from a foreign body. Often there is a question whether to remove a foreign body? On the one hand, all foreign bodies that are in the human body must be removed. On the other hand, in the absence of symptoms, the risk of surgery performed for the purpose of removal exceeds the risk associated with finding the foreign body. We would like to describe a practical case of removing a foreign body (Kirschner's wires) from the left supraclavicular region. The young patient lived with a fragment of Kirschner's wire left after the osteosynthesis of the fractured clavicle for 5 years. Surgery to remove the residual foreign body was successful. On the 7-th postoperative day the patient was discharged from the hospital under the supervision of surgeons at the place of residence.
\end{abstract}

KeyWords: foreign body in soft tissue, Kirschner`s wire, surgical treatment.

\section{INTRODUCTION}

Foreign bodies (corpus alienum) in soft tissues are common in the surgical practice. The main mechanism of entering soft tissues is domestic, mine explosion, and occupational injuries. In many cases, foreign bodies remain in the patient's body after the surgical treatment. As a rule, these are metal objects (frame plates, wires, etc.) after traumatological surgical interventions [1, 2, 3]. According to the International Red Cross Committee, foreign bodies lying deep in soft tissues should not be removed. Exceptions are as follows:

- foreign bodies causing dysfunction of vital parts (larynx stenosis, hollow organ perforation, bleeding, intestinal obstruction, etc.);

- all foreign bodies accessible during initial wound handling (around $10 \%$ of all foreign bodies);

\section{Corresponding Author:}

Anastasiia Sochnieva MD, PhD student, Department of Surgery No. 1, Kharkiv National Medical University.

E-mail: sochnevanastya@gmail.com
- foreign bodies causing significant functional disorders or exerting pressure on vessels and nerves;

- indications for late removal of foreign bodies (in case of partial or complete healing of the wound channel) may include sustained wound infection, fistula formation, repeated bleeding, pronounced painfulness.

We have faced a clinical case of a residual foreign body (fragment of Kirschner's wire) in the soft tissues after osteosynthesis of the left clavicle and would like to share our observations.

A 25-year-old patient presented to the hospital of State Enterprise "V.T. Zaitsev Institute of General and Emergency Surgery of the National Academy of Medical Sciences of Ukraine" with pain in the left supraclavicular region when lifting her 10-kg-baby, which is probably due to the irritation of nerve plexuses. At the age of 20, the patient underwent surgery for clavicle fracture and osteosynthesis with Kirschner's wires was performed. It was also found out that the frame wire was fractured during removal, and its medial part migrated to soft tissues. The patient lived with a foreign body in the left supraclavicular region for 5 years without any complaints. The patient was examined at the Institute hospital. Laboratory tests were unremarkable. Computer tomography of the thorac- 
ic organs showed that a $70 \mathrm{~mm}$ long and $3 \mathrm{~mm}$ wide fragment of wire with metal density was visualized in the soft tissues of the left supraclavicular region between the 1st rib and the scalene. The medial end of the wire was attached to C7 left half. Consolidated fracture of the outer third of the left clavicle was also visualized. Figures 1 and 2 show CT scans visualizing a foreign body (Kirschner's wire) in the left supraclavicular region.
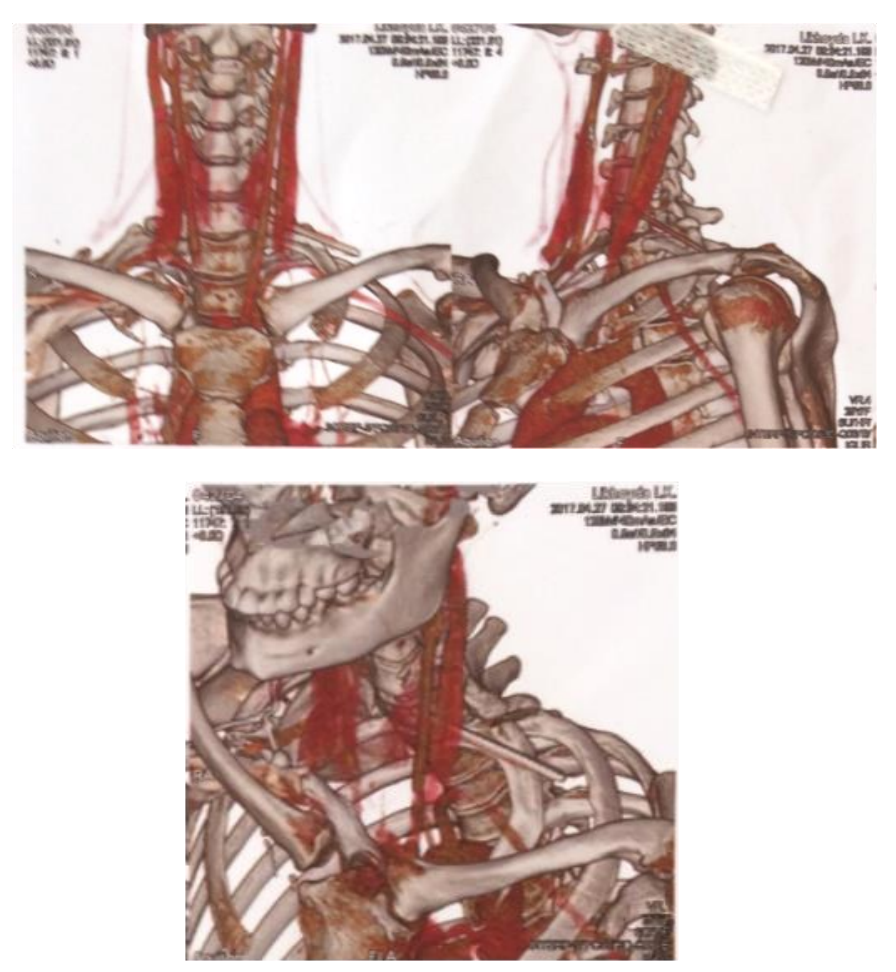

Fig. 1. CT scans visualizing a foreign body (Kirschner's wire) in the left supraclavicular region.

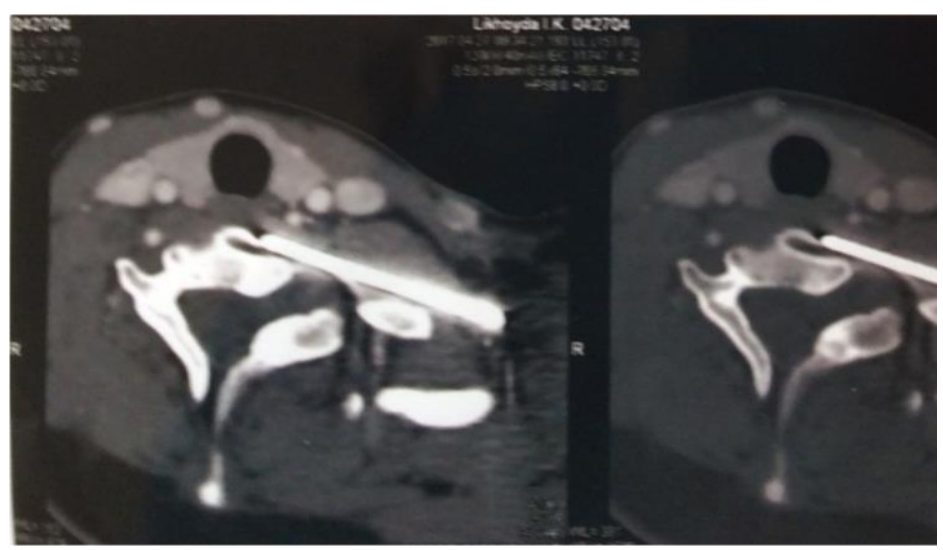

Fig. 2. CT scans visualizing a foreign body (Kirschner's wire) in the left supraclavicular region.
The foreign body was marked and its depth in the soft tissues of the left supraclavicular region was measured under ultrasound control. Many authors recommend marking the foreign body to avoid technical difficulties during its removal $[3,4]$.

On 17 May 2017, the foreign body in the left supraclavicular region was removed under general anesthesia. The skin and subcutaneous tissue over the foreign body were lanced under ultrasound control by the projection route based on the prior marking. During the instrumental inspection of the foreign body location from its lateral edge, the foreign body end was identified $2-2.5 \mathrm{~cm}$ deep under the skin, seized with the Kocher's forceps and removed (Fig. 3.). Hemostasis was dry. The post-operative wound was sutured layer-wise. The wound was drained with rubber tube drainage. lodine. Aseptic bandages.

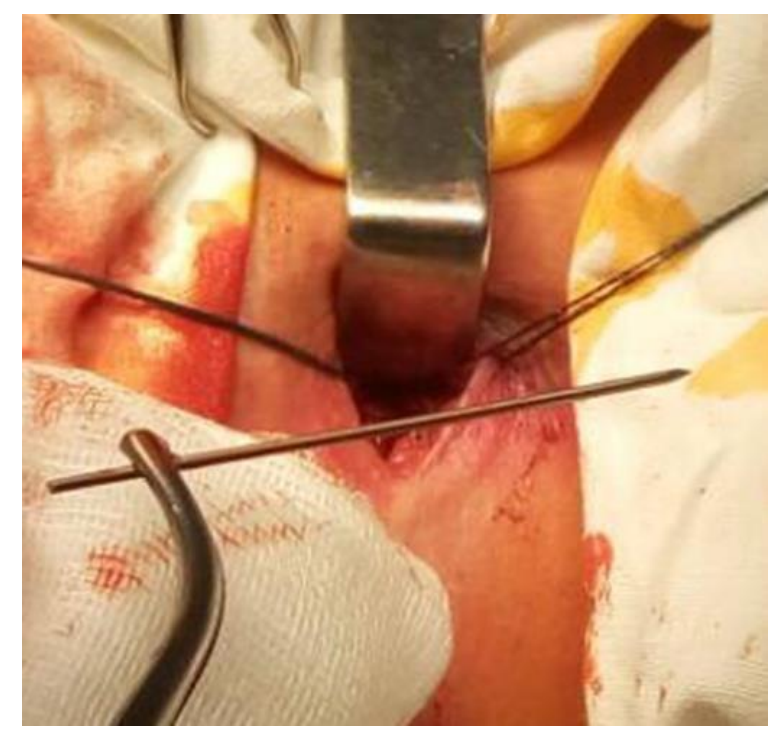

Fig. 3. A fragment of Kirschner's wire

Figure 4 shows the fragment of Kirschner's wire as compared to the size of surgical forceps. During the postoperative period, the patient received antibacterial, antiinflammatory, and infusion therapy leading to progressive improvement. She was discharged from the in-patient department 7 days later.

As a rule, Kirschner's wires are used to fix thin bones, including clavicles. After such interventions, wires should be removed 8-12 months after the surgery because clavicles usually need longer and more stable fixation $[1,5$, 6]. 
Wound Stage in Patients with Surgical Pathology Materials of the margins. Scientific-practical. Conference dedicated to the 50th anniversary of the Society of Radiologists and Radiologists. Krasnoyarsk. 2000; 37 - 38];

3. Hedrick W.R., Hykes L., Starchman D. E. (1995) Static imaging principles and instrumentation.

Fig. 4. A fragment of Kirschner's wire as compared to the size of surgical forceps.

There are cases of unsuccessful removal when the wire is fractured and its medial part migrates into soft tissues. A foreign body unnoticed or left in soft tissues becomes an infection lesion around which infiltrate or abscess is likely to form. It is also likely that a fistula may form around the foreign body. Originally, sterile foreign bodies, such as Kirschner's wires, get encapsulated after osteosynthesis without abscess, however, there is a risk of infection [7, $8,9,10]$.

\section{CONCLUSIONS}

Based on the data obtained, it can be concluded that the risk of large vessel damage and constant irritation of the nerve plexus causing clinical symptoms in patients justifies surgical interventions for the removal of residual foreign bodies in soft tissues.

\section{CONFLICT OF INTERESTS}

There is no conflict of interests.

\section{REFERENCES}

1. Vavrik Zh.M., Zelenskij R.G. (1992) Inorodnye tela organizma. Vestnik hirurgii. 4-6. 342-344; [Vavrik Zh.M., Zelenskij R.G. Foreign bodies of the organism // Herald of surgery.1992. №.4-6. S.342-344];

2. Evdokimova E.Ju., Zhestovskaja S.I. (2000) Rol' CDK $\vee$ diagnostike stadij ranevogo processa mjagkih tkanej $\mathrm{u}$ bol'nyh $\mathrm{s}$ hirurgicheskoj patologiej. Materialy kraev. nauch.-prakt. konferencii, posvjashhennoj 50-letiju obshhestva rentgenologov i radiologov. Krasnojarsk. 37 38; [Evdokimova E.YU., Zhestovskaya S.I. The Role of the Central Cancer Center in Diagnostics of the Wound Soft
Ultrasound physics and instrumentation. St. Louis (MO): Mosby. 71 -87;

4. Lavoipierre A.M., Kremer S. (1999) The expanding role of ultrasound in medicine. Aust. Fam. Physician. 28 (11). 7 ;

5. Elizarovskij S.I., Kalashnikov R.N. (1979) Operativnaja hirurgija $\mathrm{i}$ topograficheskaja anatomija. M.: Medicina 510 s.; [Elizarovskij S.I., Kalashnikov R.N. Operative surgery and topographic anatomy. M.: Medicine. 1979. P.510];

6. Kuznetsov V.A. (1963) Inorodnye tela, ostavlennye $\checkmark$ rane pri operacii. Hirurgija. 3. 93-98; [Kuznetsov V.A. (1963) Foreign bodies left in the wound during surgery. Surgery. 3. 93-98];

7. Shaposhnikov Ju.G. (1984) Diagnostika i lechenie ranenij. Moskva. 343 s.; [Shaposhnikov Yu.G. (1984) Diagnosis and treatment of wounds. Moscow. 343 p.];

8. Shljapnikov S.A. (2003) Hirurgicheskie infekcii mjagkih tkanej - staraja problema $v$ novom svete. Infekcii v hirurgii. 1(1). 14 - 21; [Shlyapnikov S.A. (2003) Surgical infections of soft tissues are an old problem in a new light. Infections in surgery. 1 (1). 14 to 21];

9. Florikjan A.K. (1998) Hirurgija povrezhdenij grudi (patofiziologija, klinika, diagnostika, lechenie): izbrannye lekcii; Har'kov. Osnova. S.510 (S.192); [Florikyan A.K. (1998) Surgery of breast lesions (pathophysiology, clinic, diagnosis, treatment): selected lectures; Kharkiv. The basis. P.510 (P.192)];

10. Hedrick W.R., Hykes L., Starchman D.E. (1995) Static imaging principles and instrumentation. Ultrasound physics and instrumentation. St. Louis $(M O)$ : Mosby. $71-87$.

Received: $\quad$ 08-May. - 2017

Accepted: 21-Sep. - 2017 